\title{
Techniques for Interpreting English Proverbs into Arabic
}

\author{
Tareq Ali Eadaroos Assaqaf \\ Associate Professor at University of Aden, Faculty of Education, Saber, Yemen \\ Associatprof.tareqassaqaf@yahoo.com
}

\begin{tabular}{|c|c|}
\hline $\begin{array}{l}\text { Received: } \\
\text { 03/04/2019 }\end{array}$ & $\begin{array}{l}\text { Abstract } \\
\text { Interpretation plays a role of a paramount significance in sending and }\end{array}$ \\
\hline $\begin{array}{l}\text { Accepted: } \\
\text { 29/06/2019 }\end{array}$ & $\begin{array}{l}\text { receiving messages between people all over the world. It is also of vital } \\
\text { significance in international conferences, symposiums and workshops } \\
\text { where the meaning must be transferred among the participants. In fact, } \\
\text { proverbs can be considered as one of the most important elements which } \\
\text { are used in speech and need to be exchanged among nations around the }\end{array}$ \\
\hline $\begin{array}{l}\text { KEYWORDS: } \\
\text { Interpreter, } \\
\text { Equivalent, } \\
\text { Translator, } \\
\text { Proverb, } \\
\text { Technique }\end{array}$ & $\begin{array}{l}\text { globe. However, interpreters usually encounter some challenges in } \\
\text { interpreting proverbs from English to Arabic or vice versa due to the } \\
\text { cultural differences between Arabic and English as well as the lack of } \\
\text { equivalents for some proverbs. This study investigates the techniques of } \\
\text { interpreting the English proverbs from English to Arabic. The data of this } \\
\text { study are collected from two basic well-known dictionaries, namely, the } \\
\text { Lamps of Experience: a Collection of English Proverbs by Ba'alabaki } \\
\text { (1980) and a Dictionary of Proverbs: English - Arabic by Kilani and Ashour } \\
\text { (1991). The analysis of data reveals that many techniques can be used for } \\
\text { the interpretation of proverbs. Such techniques are highlighted and graded } \\
\text { based on their own priorities. The present study provides } \\
\text { recommendations for interpreters, translators, researchers which might } \\
\text { improve the quality of interpreting and translating proverbs. }\end{array}$ \\
\hline
\end{tabular}

\section{INTRODUCTION}

A proverb can be defined as a short well-known sentence that contains either a general truth about life or gives an advice (Oxford Advanced Learner's Dictionary, 1995). It is considered to be the extraction of the experiences of peoples in life. Speakers, of the same and even of different speech community, usually use proverbs in order to send messages of short forms and deep meaning while communicating with one another. Some proverbs hold wisdoms while others hold some advice. English and Arabic proverbs are a case in point. To transfer wisdom or a piece of advice of a proverb from a source language (SL) into a target language (TL) is not an effortless process. In other words, interpreters have to follow a number of techniques during the process of transferring the SL message into TL message in order to precisely keep the SL message while interpreting the proverbs from the source language into the target language.

The study is mainly concerned with how the English proverbs can be interpreted into Arabic while keeping the precise message of the SL English proverb. In other words, it sheds some light on the interpretation techniques which could help the interpreters in 


\section{$\underline{\text { Techniques for Interpreting English Proverbs into Arabic }}$}

rendering the English proverbs into Arabic orally. It would contribute to improving the quality of the interpretation of proverbs from English to Arabic or vice versa. It might also facilitate the tasks of the interpreters by highlighting the efficient techniques which might benefit the interpreters in general and the interpreters of proverbs in particular.

\section{The Differences between the Work of a Translator and the Work of an Interpreter}

Unlike translators, interpreters lack the immediate access to dictionaries during the process of interpretation. Moreover, interpreters mostly work individually and rarely work in pairs but never work in groups. To make matters worse and more difficult, they have very limited time especially in case the SL speaker is sending their message at the quickest speed. On the contrary, translators tend to have a complete freedom to consult various dictionaries of all fields of study while converting the meaning from SL into TL. In addition, they have a wider time to work either in pairs, or in groups or individually. It is worth mentioning here that the effective weapon of the interpreter is using his/her mind. The interpreter has to make their minds dictionaries by themselves. In other words, s/he has to employ their minds in order to work so quickly while rendering the SL message into TL verbally.

\section{Problem Statement}

It is well-known that translating a text from one language into another is not an easy task. Translators need to take into account a number of factors among which the linguistic and cultural differences between the source and target language. The challenges encountered by the translators often arise from the lexical or syntactic gap between the source and target language. As discussed in the introduction, translators have their own sources which might be useful to overcome some translation challenges. However, interpreters cannot make use of any sources due to the time limitation. Therefore, the cultural and linguistic differences between the source and target language together with the lack of equivalents in the target language as well as the time limitation make the task of interpreters more challenging than that of translators. Literature reveals that a few studies have investigated the translation of proverbs from English to Arabic or vice versa. However, this study is mainly concerned with the techniques of interpreting the English proverbs to Arabic. It seeks to answer the following study questions:

1- What are the useful techniques which might help interpreters in rendering English proverbs into Arabic orally?

2- What are the challenges encountered by the interpreters while interpreting proverbs from English into Arabic?

\section{The Importance of the Interpretation of English Proverbs}

The importance of interpreting English proverbs lies in the following points:

a) Proverbs reflect who we are.

b) They are the mirror of life.

c) Many details can be summed up by using proverbs.

d) Proverbs touch on just about every aspect of life. Almost everything in life has a proverb. 
e) Business and proverbs are natural partners: in business, time really is money, therefore brevity is a plus. Business people are going to be attracted to pithy statements because they do not have time for lengthy discourse.

f) Proverbs, like twitter today, they are both useful and brief.

g) People may sometimes not understand a big lecture but they understand a small proverb very easily.

h) The language of proverbs is simple but picturesque.

i) Using them in the best possible way will make one feels more confident than others speaking normal language.

\section{The Proposed Techniques for Interpreting English Proverbs into Arabic}

These suggested techniques are selected and graded by the researcher according to their own priorities. They are as follows:

1. By using a TL Arabic formal ready-made equivalent.

2. By using a TL Arabic semi-formal ready-made equivalent.

3. By using a TL Arabic idiomatic ready-made equivalent. This technique includes five sub-techniques: they are:

a. By using a ready-made TL proverb in Arabic.

b. By using a Qur'anic verse.

c. By using a saying quoted from Mohammed, the Prophet, God's blessing and peace be upon him.

d. By quoting a poetic verse.

e. By composing a poetic verse.

4. By reproducing a TL Arabic statement holding the same wisdom or advice of the SL English proverb.

5. By using the process of literal interpreting as a last resort.

All these techniques must be working quickly inside the interpreter's mind. Interpreters should use alternatives at the highest speed and should never waste time.

\section{METHODOLOGY}

The study adopts the qualitative approach for collecting and analyzing the data of this study. The collected data of this study, i.e. the selected English proverbs to be translated into Arabic are collected from a number of various accredited dictionaries, namely, The Lamps of Experience: A Collection of English Proverbs with Origins and Arabic Equivalents by Ba'alabaki (1980), A Dictionary of Proverbs: English - Arabic by Kilani and Ashour (1991), Oxford Advanced Learner's Dictionary of Current English by Hornby (1995), Longman Dictionary of English Language and Culture by Delahunty et al. (1992), Longman Advanced American Dictionary by Campbell et al. (2000), and Longman Dictionary of Contemporary English by Marwick et al. (1995). The collected data are also gathered from an Arabic book about translation, namely, أوضح الاساليب في الترجمة والتعريب (The Clearest techniques in Translation and Transliteration) by Sayej and Aquel (1993). The next section provides the data analysis of the current study.

\section{Data Analysis}




\section{$\underline{\text { Techniques for Interpreting English Proverbs into Arabic }}$}

The first applicable technique is by using a TL Arabic ready-made formal equivalent which means using another proverb already available in Arabic language. This technique stimulates the interpreter to use a TL Arabic proverb identical in form and meaning of the SL English proverb. The following examples are useful to illustrate this point:

\section{a- Do not put all your eggs in one basket}

The above mentioned English proverb advises ones, viz. businessmen, to trade in many projects so that in case some projects fail, the others can succeed (Kilani and Ashour, 1991). The above mentioned English proverb can be converted verbally into the following TL Arabic ready-made formal equivalent:

"لا تضع جميع بيضك في سلة واحدة"

(la tadha' Jamee' beidhuka fee salaten waheda).

b- Strike while the iron is hot

It means to make use of a favourable occasion or chance as soon as possible without wasting time. Hence the TL Arabic formal ready-made equivalent is:

"إطرق الحديد وهو ساخن"

(etreq elhaded wahwa sakhenon)

It is noticed that the form and meaning of the SL proverbs and the two TL Proverbs are both identical.

The second applicable technique which is using a TL Arabic semi-formal ready-made equivalent can be applied as a second alternative in case the interpreter could not find a TL Arabic formal ready-made equivalent. Take the following SL English proverb as an example:

\section{a- A bird in the hand is worth two in the bush}

This proverb advises one to be content with few possessions in hand rather than many possessions which are out of hand. This SL English proverb has a semi-formal TL equivalent in Arabic which is:

"عصفور في اليد خير من عشرة على الثجرة"

('sforon fe alyadi khayron men asharatn ala ashajara)

(A sparrow in hand is better than ten on the tree)

Though both of the SL English proverbs and TL Arabic proverbs hold the same message, they are slightly different in terms of vocabulary and number. Whereas the TL Arabic proverb uses the words: sparrow, better, ten and tree, the SL English proverb uses the words: bird, worth, two and bush respectively.

The third applicable technique is by using a ready-made idiomatic equivalent which is of paramount significance since it can be applied in case the first and the second technique cannot be employed. This means that if the interpreter can neither find the TL ready-made formal equivalent nor the semi-formal equivalent, then s/he is advised to use the third 
technique, especially when the interpreter has a restricted or no time to think of appropriate alternatives. This technique involves the interpreter to entirely reproduce the form of the SL English proverb into a new form in TL Arabic. Moreover, this technique consists of a number of sub-techniques which in turn have to be applied progressively. These subtechniques will be discussed in more details.

The first sub-technique is by using a ready-made proverb in Arabic that is different in form but holds the same SL message. For example, the English proverb:

\section{a- A leopard cannot change its spots}

This proverb can be reproduced into the following Arabic proverb:

"الطبع غلب التطبع"

(altab'o ghalaba atatab'o)

(The inscription overpowers the acquired character)

\section{b- When you are at Rome, do as the Romans do}

This can be reproduced into the Arabic proverb:

$$
\text { "إن كنت في قوم فأحلب في إنائهم" }
$$

(en kunta fee qumen fahloob men ena'ehim)

(If you belong into a nation, then milk in their vessel)

Though both of the SL English proverbs are completely different in form of the TL Arabic proverbs, they hold the same message of the TL Arabic proverbs.

The second sub-technique which is quoting a Qur'anic verse from the Holy Qur'an can be used in case the previous sub-technique cannot be applied. To illustrate the point, let us have the examples of the following two English proverbs:

\section{a- Death has no calendar \\ b- Death is a glass, everyone will drink it}

Whereas the former proverb indicates that death comes suddenly and has no identified time, the latter proverb shows that everyone will face death (Kilani and Ashour, 1991). Both proverbs can be reproduced into the following Qur'anic verses respectively:

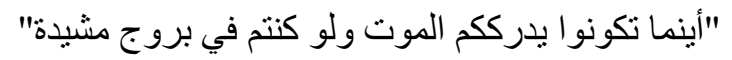

(aynama takono yodrikokom elmot walao kontom fee brojin mushiadaton)

(Whenever you are, death is reaching you, even if you are in erected towers)

"كل نفس ذائقة الموت"

\section{(kulo nafsen dha'eqaton almoot)}

(Every soul will taste death)

In case the above sub-technique cannot be applied by the interpreter, the sub-technique quoting a saying from Mohammed, the Prophet, God's blessing and peace be upon him, can 


\section{$\underline{\text { Techniques for Interpreting English Proverbs into Arabic }}$}

be applied. To make the point clear, the following English proverb is provided as an example:

\section{a- A man is known by the company he keeps.}

This proverb can be idiomatically transferred into:

$$
\begin{aligned}
& \text { "المرء على دين خليله ، فلينظر أحدكم من يخالل" } \\
& \text { (almar'o ala deene khaleelhe, flyanzoro ahadokom men yokhalel) }
\end{aligned}
$$

(The man is on the religion of their intimate friend, so each one ought to look into whom to be a friend with).

In case the previous sub-technique cannot work out, the sub-technique of quoting a wellknown Arabic literary poetic verse can also be applied. Rendering the following two SL English proverbs into the following Arabic poems respectively are a case in point:

a- The abundance of money ruins youth

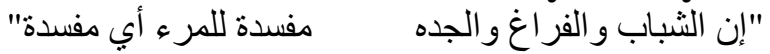

(enna ashababa wa alfaragh wa aljedah mafsadatoon lelmar'e ayo mafsadah)

(Youth and a free time are both canker)

\section{b- Actions speak louder than words \\ "السيف أصدق أنباء من الكتب في حده الحد بين الجد و اللعب"}

(asaifu asdaque enba'n men alkutobi fee hadihi alhadu baina aljeda wa ala'ebi)

(The sword is more telling than the pen; along its edge lies the boundary between serious and frivolous )

In case the interpreter cannot find a well-known Arabic poetic verse, then s/he can compose a poetic verse which holds the same wisdom or advice of the SL English proverb. This can be processed as a last resort of the third applicable technique of using a ready-made idiomatic equivalent. Of course this final sub-technique entails the interpreter to be a poet or at least be skillful in composing poetry.

If all these already discussed applicable techniques cannot be employed, then it is inescapable for the interpreter to apply the fourth applicable technique which is reproducing a TL Arabic statement that holds an identical message of the SL English proverb. In other words, the reproduced TL message here is not necessarily to be proverbial nor rhythmic nor poetic, since spotting and transferring the SL message should be the main goal. To exemplify this, the already mentioned English proverb can be presented here:

\section{a- A bird in the hand is worth two in the bush}

As previously mentioned, this proverb is best be interpreted into the Arabic proverb:

"عصفور في اليد خير من عشرة على الثجرة "

(osforon fe alyadi khayron men asharatn ala ashajara)

(A sparrow in hand is better than ten on the tree) 
That means by using the second suggested applicable technique which is using a readymade semi-formal equivalent which is identical in meaning but slightly different in form of the SL English proverb. But what about in case the interpreter does not remember the previous TL Arabic proverb or even does not know it? How can s/he behave in such a situation? In this case, it is workable to interpret it by using a statement that holds the same message such as:

"إقنع بما معكل"

(eqna' bema ma'ka)

(Be content with what you own)

The point here is that the following vocabulary of the English proverb: bird, hand and bush are not crucial to the SL message.

The final applicable technique of using the literal interpretation is achieved as a last resort, in case ready-made of formal, semiformal, idiomatic equivalent or even a statement that holds the same SL message are not available or cannot be employed, or in case the SL message of the English proverb cannot be fully comprehended by the interpreter. This technique does not necessarily involve copying out formally the English proverb into Arabic but rather it involves the interpreter to transfer the SL message literally but carefully into Arabic. The following proverb can be provided as an example:

\section{a- Better bend than break}

This proverb can be rendered into Arabic as:

"أن تميل وتتحني خير من أن تتكسر"

(an tameel wa tanhani khairon men an tankaser)

(To bent and get down is better than to break)

Of course this English proverb is better be interpreted by reproducing it idiomatically into the following Arabic proverb:

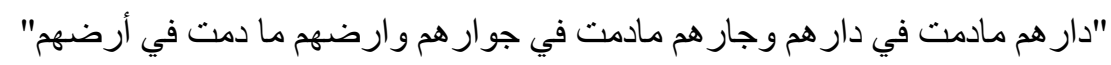

(darhim madomta fi darhim wa jarehim madomta fi jiwarehim wardhehim madomta fi ardhehim).

(Go with them since you are at their home, agree with them since you are beside them and satisfy them since you are at their land)

In case this technique cannot be applied, the technique of processing the previous proverb literally can offer some help since meaning, which is the main goal, is conveyed.

\section{CONCLUSION}

It might be concluded that there are five applicable techniques for interpreting English proverbs into Arabic proposed by the researcher. They are as follows:

1. By using a TL Arabic formal ready-made equivalent,

2. By using a TL Arabic semi-formal ready-made equivalent. 


\section{$\underline{\text { Techniques for Interpreting English Proverbs into Arabic }}$}

3. By using a TL Arabic idiomatic ready-made equivalent. This technique includes five sub-techniques. They are:

a) By quoting a ready-made TL Arabic proverb.

b) By quoting a Qur'anic verse from the Holy Qur'an.

c) By quoting a saying from Mohammed, the prophet, God's blessing and peace be upon him.

d) By quoting a poetic verse.

e) By composing a poetic verse.

4. By reproducing the SL English proverb into a TL Arabic statement that holds the same wisdom or advice.

5. As a last resort, by using the process of literal interpreting.

Finally, these suggested applicable techniques are systematically selected and graded. In case the first suggested applicable technique cannot offer any help, the interpreter must not hesitate to apply the second suggested applicable technique, and in case the second one cannot be applied, the interpreter has to move on to the third applicable technique and so on and of course the process of transferring from one technique into another must take place at the maximum speed in the interpreter's mind.

\section{References}

Ba'alabaki, M. (1980). The Lamps of Experience: A Collection of English Proverbs with Origins and Arabic Equivalents. Lebanon: Dar EL-Ilm Lil-Malayen.

Campbell, R., Clevenger, R. Hamer, M. Handorf, S. and Johnston, D. (2000). Longman Advanced American Dictionary. Edinburgh. Longman

Delahunty, A. Axbey, S. Curry, C. Dean, B. Feinstein, J. and Marwick, K. (1992). Longman Dictionary of English Language and Culture. England. Longman.

Hornby, A. (1995). Oxford Advanced Learner's Dictionary of Current English. Oxford. Oxford University Press.

Kilani, T., and Ashour, N. (1991). A Dictionary of Proverbs: English - Arabic. Lebanon: Librairie du Liban.

Marwick, K., McGregor, E. and Stern, K. (1995). Longman Dictionary of Contemporary English. England. Longman.

Sayej, P. Aquel, J. (1993). The Clearest Techniques in Translation and Transliteration. Beirut. Lebanon Library. 